\title{
The Sahara as a Bridge, Not a Barrier: An Essay and Book Review on Recent Transregional Perspectives
}

\author{
Steffen Wippel
}

Received: 12 November 2019 / Accepted: 20 May 2020 / Published online: 24 September 2020

(C) The Author(s) 2020

\begin{abstract}
In the course of the spatial turn, long-established regional subdivisions of the world have been deconstructed, and area studies are increasingly opening up for transregional research. One (re)emerging research field is Trans-Saharan Studies, which considers historical and contemporary entanglements between the Maghreb, the Sahara and the Sahel (with further connections far beyond). Against this background, Steffen Wippel's essay reviews six recently published works that can be assigned to trans-Saharan research: two comprehensive textbooks and a catalogue written in French, two edited volumes that tackle entangled trans-Saharan and transMediterranean migration flows and a study of an enclosed, yet widely interconnected inner-Saharan place and population group.
\end{abstract}

Keywords Area studies - metageographies · transregional entanglements - Sahara · Maghreb · Sahel

S. Wippel $(\bowtie)$

Philipps-Universität Marburg, Marburg, Germany

E-Mail: steffen.wippel@uni-marburg.de 


\section{Die Sahara als Brücke, nicht als Hürde: Essay und Buchkritik zu jüngeren transregionalen Perspektiven}

Zusammenfassung Im Zuge des spatial turn wurden regionale Unterteilungen der Welt dekonstruiert, die sich über lange Zeit verfestigt hatten, während sich die Regionalwissenschaften (respektive area studies) zunehmend transregionaler Forschung öffnen. Ein (wieder) aufkommendes Forschungsfeld sind Transsaharische Studien, die historische und zeitgenössische Verflechtungen zwischen dem Maghreb, der Sahara und dem Sahel (einschließlich weiterer darüber hinausgehender Verbindungen) untersuchen. Vor diesem Hintergrund rezensiert der Beitrag von Steffen Wippel sechs vor Kurzem veröffentlichte Arbeiten, die sich der transsaharischen Forschung zuordnen lassen: zwei überblicksartige Lehrbücher und einen Ausstellungskatalog, die auf Französisch vorliegen, zwei Sammelbände, die miteinander verflochtene transsaharische und transmediterrane Migrationsbewegungen $\mathrm{zu}$ fassen versuchen, sowie die Studie einer abgelegenen und dennoch weithin verbundenen Örtlichkeit und Bevölkerungsgruppe inmitten der Sahara.

Schlüsselwörter Regionalwissenschaften $\cdot$ Metageografien $\cdot$ transregionale Verflechtungen $\cdot$ Sahara $\cdot$ Maghreb $\cdot$ Sahel

The last two decades have seen an increased number of publications on contacts and entanglements crossing and passing over the Sahara. This is very much related to developments that have directed the focus of politics, media and the broader public, but also of academic research, to an area of entanglement stretching between the Sahel and the Mediterranean and, in fact, even far beyond. At the same moment, emerging theoretical and conceptual approaches, too, have moved long-neglected spatial connectivities that transgress established regional conceptions into the centre of scholars' attention. Before reviewing six publications that can be considered part of the field of trans-Saharan research, the following sections will, first, deal with transregional studies as an approach to overcome fixed 'metageographies' against the background of more constructivist perspectives and, second, give an overview of the field of (Trans-)Saharan Studies.

\section{Area Studies, the Spatial Turn and the Deconstruction of Fixed Metageographies}

Among the many conceptual turns experienced by the humanities and social sciences in the last decades, the progressively expanding 'spatial turn' has had two major consequences: first, across the disciplines, it sparked a new empirical interest in the inherent spatiality of human life, which had long been neglected in the modernist Western worldview. Second, new critical, theoretical and conceptual approaches to the 'production of space', in particular based on Henri Lefebvre's seminal work ${ }^{1}$,

\footnotetext{
1 Lefebvre, Henri: La production de l'espace, Anthropos, Paris 1974.
} 
have gained momentum, mostly taking recourse to perspectives introduced by social constructivism. ${ }^{2}$

For a long time in human and social research, a static and essentialist image of relevant spaces prevailed. According to this mostly implicit idea, social activities went on in predefined spatial 'containers'. However, this methodological focus limited our ability to adequately understand (and even perceive) important phenomena unfolding between predefined territories, especially in an era of accelerated globalisation. Contrary to these rigid conceptualisations, social space is now mostly interpreted as being historically and socially constituted, i.e. continuously (purposefully or unintentionally) produced, reconfigured and transformed by human acts, ideas and communication. ${ }^{3}$ Scholars endeavour to deconstruct socio-spatial contexts and prove their variability and permeability. The production of space can be observed at several (e.g. national, regional and global) shifting and interpenetrating scales. $^{4}$

A central issue, first of all, is the concept of the territorial nation state (TNS), which conflates the three name-giving components into a single phenomenon. ${ }^{5}$ This "methodological nationalism" has been intensely questioned, and John Agnew's warning against the "territorial trap"7 has been widely acknowledged. Earlier, other prominent authors like Benedict Anderson ${ }^{8}$ and Eric Hobsbawm ${ }^{9}$ already considerably contributed to a constructivist understanding of the state and the nation in human and social research. Conceptual approaches also focus on the ambivalent meaning of interterritorial borders. On the one hand, they constitute barriers to material and human movement and provide repeated sources of conflict. On the other hand, they are now being conceived as interfaces, offering opportunities for social and economic interaction and signifying geographical and social proximity. ${ }^{10}$

\footnotetext{
2 The subsequent explanations are based in, among other writings, Wippel, Steffen: Wirtschaft, Politik und Raum. Territoriale und regionale Prozesse in der westlichen Sahara, Schiler, Berlin/Tübingen 2012; idem (ed.): Regionalizing Oman. Political, Economic and Social Dynamics, Springer, Dordrecht 2013; idem: All Things Transregional?, in: Forum Transregionale Studien/Max Weber Stiftung (eds.): All Things Transregional? A Conversation About Transregional Research, Bonn/Berlin 2019, pp. 74-82.; Wippel, Steffen/ Fischer-Tahir, Andrea (eds.): Jenseits etablierter Meta-Geographien. Der Nahe Osten und Nordafrika in transregionaler Perspektive, Nomos, Baden-Baden 2018.

${ }^{3}$ For an overview, see Bachmann-Medick, Doris: Cultural Turns. Neuorientierungen in den Kulturwissenschaften, Rowohlt, Reinbek bei Hamburg 2006.

${ }^{4}$ E.g. Sassen, Saskia: Globalization or Denationalization?, in: Review of International Political Economy 10 (2003), No. 1, pp. 1-22.

${ }^{5}$ E.g. Delaney, David: Territory. A Short Introduction, Blackwell, Malden, MA 2005.

${ }^{6}$ Wimmer, Andreas/Glick Schiller, Nina: Methodological Nationalism and Beyond. Nation-State Building, Migration and the Social Sciences, in: Global Networks 2 (2002), No. 4, pp. 301-334.

7 Agnew, John: The Territorial Trap. The Geographical Assumptions of International Relations Theory, in: Review of International Political Economy 1 (1994), No. 1, pp. 53-80.

8 Anderson, Benedict: Imagined Communities. Reflections on the Origin and Spread of Nationalism, Verso, London 1983.

9 Hobsbawm, Eric J.: Nations and Nationalism Since 1780. Programme, Myth, Reality, Cambridge UP, Cambridge 1990.

${ }^{10}$ Cf. also Nugent, Paul/Asiwaju, Anthony I. (eds.): African Boundaries. Barriers, Conduits and Opportunities, Pinter, London/New York 1996.
} 
Parallel to the TNS, other spatial narratives have been put into question, namely the existence of regional entities as another consolidated and unquestioned frame of analysis. Already, there is no uniform understanding of the term 'region' ${ }^{11}$; definitions depend on academic disciplines, theoretical predispositions and research questions. In very general terms, the notion relates to a meaningful subdivision of the earth's surface into more or less continuous geographical entities that range from micro-regional to continental configurations. Academic regionalisations are mostly drawn on the basis of certain functional criteria or structural commonalities. They still often follow the principle of homogeneity, i.e. in reference to the similarity of one or several (i.e. religious, linguistic, natural or economic) attributes.

On the macro-level, thinking in terms of a small number of-mostly (quasi-)continental-world regions as seemingly given and fixed spatial structures continues to predominate. Initially, larger subdivisions of the world were mostly delineated in accordance with physical features, namely continental landmasses. ${ }^{12}$ But notably since the dissolution of the two global political blocs, cultural definitions that never entirely disappeared have gotten a boost again. World regions are then often conceived as apparently clearly defined 'cultural continents', as presented in academia, from older German cultural geography ${ }^{13}$, echoing the anthropological Kulturkreislehre (cultural field school) ${ }^{14}$, to Samuel Huntington's 'civilizational worlds', who took up fundamental ideas from the classical strand of the realist school of International Relations. ${ }^{15}$ However, these attributions are normatively charged and strategically used to transport (geo)political ambitions in specific historical constellations (such as colonialism and the Cold War). ${ }^{16}$

Finally, the ubiquity of the territorial principle made states the building blocks of world regions. Like the state's territorial organisation, pervasive representations of world regions are continuously conveyed in state institutions and public media and shape public understanding of the world from childhood on. Notably, maps with their coloured contiguous areas give especially continental landmasses, like

\footnotetext{
${ }^{11}$ Miggelbrink, Judith: Der gezähmte Blick. Zum Wandel des Diskurses über „Raum“ und „Region“ in humangeographischen Forschungsansätzen des ausgehenden 20. Jahrhunderts, Institut für Länderkunde, Leipzig 2002, p. 95.

12 Lewis, Martin W./Wigen, Kären E.: The Myth of Continents. A Critique of Metageography, California UP, Berkeley, CA et al. 1997; Grataloup, Christian: L'invention des continents. Comment l'Europe a découpé le monde, Larousse, Paris 2009.

${ }^{13}$ E.g. Newig, Jürgen: Drei Welten oder eine Welt. Die Kulturerdteile, in: Geographische Rundschau 38 (1986), No. 5, pp. 262-267.

${ }^{14}$ Haller, Dieter: Geister im Raum. Cultural Areas in Zeiten der ontologischen Wende, in: Wippel/FischerTahir (eds.): Meta-Geographien (see footnote 2), pp. 71-90.

15 Huntington, Samuel P.: The Clash of Civilizations?, in: Foreign Affairs 72 (1993), No. 3, p. 22-49. For a historical-disciplinary appraisal, cf. Orsi, Davide: The 'Clash of Civilizations' and Realism in International Political Thought, in: E-International Relations, 15 April 2018, URL: <https://www.e-ir.info/ 2018/04/15/the-clash-of-civilizations-and-realism-in-international-political-thought/> [accessed: 25 May 2020].

${ }^{16}$ Cf. also Fassmann, Heinz/Wardenga, Ute: Der Begriff Mitteleuropa in politisch-geographischer Sicht, in: Geographische Rundschau 51 (1999), No. 1, pp. 26-31.
} 
state territories, a precise and easily memorable "good shape" ${ }^{17}$ In the academic realm, 'area studies' (and regional specialisations in the more systematic disciplines) contributed considerably to the solidification of certain world areas and the creation of rigid "conceptual empires". ${ }^{18}$ This again sometimes obscures rather significant historical and current contexts, connections and relationships that do not conform to predefined containers.

Martin Lewis and Kären Wigen interpret such conventionally regarded, mutually exclusive regional entities as historically produced and mentally rigidified "metageographies" that have been classified in accordance with seemingly objective criteria and help people order their knowledge of the world. ${ }^{19}$ Instead, they plead for a "critical metageography" and propose to consider alternative patterns of spatial arrangements and mobilities that transgress and crosscut continents, regions and states. In this context, numerous case studies by geographers, historians and political scientists have endeavoured to show the academic and political 'making' of regions and to point to their continuous reconfiguration and transgression. ${ }^{20} \mathrm{~A}$ wide range of regionalisation processes is being studied, which can go along with the institutionalisation and sedimentation, but also with the disintegration and disappearance of regions. Sometimes they even constitute discontinuous, network- and archipelagolike spheres. ${ }^{21}$ Hence today, the notion of 'region' refers to a relative historical entity fluctuating in time and space and is considered a heuristic and preliminary working concept.

${ }^{17}$ See Schlicht, Ekkehart: Individuelles Streben und kulturelles Gefüge, in: Ökonomie und Gesellschaft. Jahrbuch 8: Individuelles Verhalten und kollektive Phänomene, Campus, Frankfurt a. M./New York 1990, pp. 112-127.

18 Van Schendel, Willem: Geographies of Knowing, Geographies of Ignorance. Jumping Scale in Southeast Asia, in: Kratoska, Paul H./Raben, Remco/Nordholt, Henk Schulte (eds.): Locating Southeast Asia. Geographies of Knowledge and Politics of Space, Singapore UP/Ohio UP, Singapore/Athens, OH 2005, pp. 275-307, here p. 276; cf. also Kratoska, Paul H./Raben, Remco/Nordholt, Henk Schulte (eds.): Locating Southeast Asia. Geographies of Knowledge and Politics of Space, Singapore UP/Ohio UP, Singapore/ Athens, OH 2005 on South East Asian Studies, and Khalidi, Rashid: The "Middle East" as a Framework of Analysis. Re-mapping a Region in the Era of Globalization, in: Comparative Studies of South Asia, Africa and the Middle East 18 (1998), No. 1, pp. 74-80 on Middle Eastern Studies. For further reading on regional and transregional studies, cf. especially Middell, Matthias (ed.): Self-Reflexive Area Studies (Global History and International Studies, Vol. 5), Leipziger UV, Leipzig 2013; Sidaway, James D.: Geography, Globalization, and the Problematic of Area Studies, in: Annals of the Association of American Geographers 103 (2013), No. 4, pp. 984-1002; Mielke, Katja/Hornidge, Anna-Katharina (eds.): Area Studies at the Crossroads. Knowledge Production After the Mobility Turn, Palgrave Macmillan, Basingstoke/New York 2017; Derichs, Claudia: Knowledge Production, Area Studies and Global Cooperation, Routledge, London/New York 2017.

19 Lewis/Wigen: Myth (see footnote 12).

${ }^{20}$ E.g. Schultz's works on continuously changing constructions of macro-regions like "Central Europe" (Mitteleuropa) and "Europe" in the history of geography: Schultz, Hans-Dietrich: Räume sind nicht, Räume werden gemacht. Zur Genese „Mitteleuropas“ in der Deutschen Geographie, in: Europa Regional 5 (1997), No. 1, pp. 2-14; idem: Europa als geographisches Konstrukt, Friedrich-Schiller-Universität Jena, Institut für Geographie, Jena 1999.

${ }^{21}$ Cf. also Veltz, Pierre: Mondialisation, villes et territoires. L'économie d'archipel, PUF, Paris 1997. 


\section{A Trans-Regional Research Perspective}

In consequence, there have been differing conceptual and methodological reactions to the acknowledged 'crisis' of area studies. At the one end, 'comparative area studies' is a field that has particularly emerged in political sciences to overcome parochial perspectives in area studies, ${ }^{22}$ but still risks regressing to comparing across predefined regions. ${ }^{23}$ At the other end of the spectrum, with the rising debate on 'globalisation', there has been a tendency to completely abandon regional approaches by diluting them in encompassing 'global studies'.

But recognising that sub-planetary contexts are perhaps more relevant to human action than an entirely 'flat' world, more specific 'transregional studies' have emerged as a new field of research — as both a conceptual perspective and an object of study. These new perspectives often operate with a series of socio-spatial and overlapping 'trans'-terms such as transnational ${ }^{24}$, trans-state ${ }^{25}$, trans-area ${ }^{26}$ and essentially transregional. ${ }^{27}$ Furthermore, South-South relations in global history and the agency of people in the Global South are being carved out, notably under the research perspective of 'translocality' ${ }^{28}$ Unlike purely comparative area studies, which focus on comparing structures and processes, such 'trans'-studies mostly investigate connections, mobilities, entanglements and networks that produce differentiated and multi-layered spatial contexts. The prefix 'trans' points to meanings like 'across' ${ }^{29}$ 'over', 'beyond' et cetera. Hence, the transspatial can extend across a predefined

\footnotetext{
22 Besides intraregional comparison, especially interregional and cross-regional perspectives (i.e. comparison of entire regions vs. of entities across different regions) are being proposed and emphasized. Cf., for instance, Basedau, Matthias/Köllner, Patrick: Area Studies, Comparative Area Studies, and the Study of Politics: Context, Substance, and Methodological Challenges, in: Zeitschrift für Vergleichende Politikwissenschaft 1 (2007), No. 1, pp. 105-124; Mehler, Andreas: Comparative Area Studies, in: Middell, Matthias (ed.): The Routledge Handbook of Transregional Studies, Routledge, London/New York 2018, pp. 67-73.

23 E.g. Derichs, Claudia: Knowledge Production (see footnote 18), p. 168, critically annotates that, for comparative area studies, "the prior definition and delineation of the units of comparison closes the road for detecting the unconventional, the unconceptualised, the untheorized".

24 Pries, Ludger: Transnationalism and Migration. New Challenges for the Social Sciences and Education, in: Luchtenberg, Sigrid (ed.): Migration, Education and Change, Routledge, London/New York 2004, pp. 15-39.

25 Bach, Daniel C. (ed.): Régionalisation, mondialisation et fragmentation en Afrique subsaharienne, Karthala, Paris 1998.

26 Houben, Vincent: New Area Studies, Translation and Mid-Range Concepts, in: Mielke/Hornidge (eds.): Area (see footnote 18), pp. 195-211, here p. 204; Sidaway: Geography (see footnote 18), p. 992.

27 Cf. also Middell, Matthias: Are Transregional Studies the Future of Area Studies?, in: Mielke/Hornidge (eds.): Area (see footnote 18), pp. 289-307, here pp. $299 \mathrm{f}$.

28 Freitag, Ulrike/von Oppen, Achim (eds.): Translocality. The Study of Globalising Processes from a Southern Perspective, Brill, Leiden/Boston, MA 2010; Bromber, Katrin: Working with "Translocality". Conceptual Implications and Analytical Consequences, in: Wippel (ed.): Regionalizing (see footnote 2), pp. 63-74.

29 Similarly, 'Crossroads Studies' endeavour to transcend conventional ideas of concretely delimited and territorially fixed regions, instead examining spatial intersections and contact areas based on the dynamisms of human (im)mobilities, (communicative) interactions and negotiations of boundaries. Cf. Hornidge, Anna-Katharina/Mielke, Katja: Crossroads Studies: From Spatial Containers to Studying the Mobile, in: Middle East-Topics and Arguments 4 (May 2015), pp. 13-19.
} 
container, as we find it for some transport infrastructure or political unification projects. Vice versa, and this is mostly meant, it goes beyond given spatial borders such as states and world regions, but also physical markers.

Accordingly, rivers, seas and ocean ${ }^{30}$, as well as mountain ranges and vast deserts, are also coming into focus. For a long time, they have been considered barriers to trade and exchange rather than interstitial or literally 'medi-terranean' ${ }^{31}$ zones facilitating close regional links, entanglement and transit. Corresponding empirical research has been done, for instance, on the (trans-)Mediterranean region ${ }^{32}$ and the Indian Ocean worlds ${ }^{33}$, but also on (trans-)Saharan spaces (see below). Often, contemporary links are related to historical connections, yet such regionalisation processes are not only replications of the past as, e.g., relevant actors, commodities, transport means and routes have changed considerably. In part, such 'transregional' contacts - at least in certain social spheres-are even stronger than within the allegedly 'same' region. Finally, this includes thinking about the limits of linguistic expression, particularly the naming of reconstructed regional contexts. Sometimes, very creatively, we are able to invent new names (like Willem van Schendel's "Zomia" ${ }^{4}$ ) or to refer to old, forgotten and local, emic designations. Yet, to avoid too-artificial notions, we also take up existing names, sometimes with prefixes like 'trans' or less common compositions (such as 'trans-Saharan', 'Maghreb-Sahel', 'the wider Western Sahara' or 'Northwest Africa' for the region studied below).

In any case, a transregional perspective allows for bringing together research that is typically separated in accordance with regionally and disciplinarily assorted knowledge (and in part, theory) production. In fact, numerous scholars have worked 'transregionally', sometimes for decades, even if they have not been or are still not aware of being part of such a research strand. ${ }^{35}$ Notably outside the German-speaking world, the label 'transregional' is much less common, even if transregional studies also have gained much momentum there. ${ }^{36}$ By now, a number of edited volumes with international contributions have been published that inspect the field of regional and transregional studies. ${ }^{37}$ Increasingly, new research groups, academic institutions and even courses of study have been established. But also in state institutions, awareness of problem areas cross-cutting established administrative competencies has resulted in the (temporary) establishment of, e.g., an Indian Ocean expert group

\footnotetext{
30 E.g. Bentley, Jerry H./Bridenthal, Renate/Wigen, Kären (eds.): Seascapes. Maritime Histories, Littoral Cultures, and Transoceanic Exchanges, Hawaii UP, Honolulu, HI 2007.

31 Attinà, Fulvio: Regional Cooperation in Global Perspective. The Case of the "Mediterranean" Regions, University of Catania, Department of Political Studies, Jean Monnet Chair of European Comparative Politics, Catania 1996; cf. also Rothermund, Dietmar/Weigelin-Schwiedrzik, Susanne (eds.): Der Indische Ozean. Das afro-asiatische Mittelmeer als Kultur- und Wirtschaftsraum, Promedia, Vienna 2004.

32 E.g. Dabag, Mihran et al. (eds.): Handbuch der Mediterranistik. Systematische Mittelmeerforschung und disziplinäre Zugänge, Schöningh, Paderborn et al. 2015.

33 Cf. also Deutsch, Jan-Georg/Reinwald, Brigitte (eds.): Space on the Move. Transformations of the Indian Ocean Seascape in the Nineteenth and Twentieth Century, Schwarz, Berlin 2002.

34 Van Schendel: Geographies (see footnote 18).

35 Cf. also Forum Transregionale Studien/Max Weber Stiftung (eds.): Things (see footnote 2).

36 Goebel, Michael: All Things Transregional?, in: Forum ... (eds.): Things (see footnote 2), pp. 63-68.

37 Cf. also Middell, Matthias (ed.): Handbook (see footnote 22).
} 
in the German Foreign Office and, on the EU level, first insight that Maghreb and Sahel issues should be tackled jointly ${ }^{38}$ (for curricular innovation in the French higher education system, cf. below).

\section{The Emerging Field of (Trans-)Saharan Studies}

One field of transregional research is (re-)emerging Trans-Saharan Studies. ${ }^{39}$ The traditional subdivision of the 'Old World' from ancient times was the trisection into the European, African and Asian continents. ${ }^{40}$ Likewise, there is a deeply rooted dichotomy between the Occident and the Orient. From a Western perspective, this often has been accompanied by rather pejorative moral and cultural connotations concerning its Eastern counterpart; accordingly, Edward Said prominently stigmatised this stance as "Orientalism". ${ }^{41}$ Locally, a similar understanding traditionally distinguishes the western and eastern parts of the Arab world, the Maghreb and the Mashreq.

In contrast to the repeated flows of commodities, people and ideas across the Sahara to adjacent and more distant regions in the first half of the second millennium, in the second half, European penetration into Africa and technological changes in the shipping industry have considerably disturbed these exchanges and reorientated them towards the continent's maritime coasts and sea trade. Continuing trade and pilgrimage routes were nearly entirely cut in the heyday of Western imperialism in the late 19th and early 20th centuries, when European powers tried to control these movements and establish colonial territories and borders. Paralleling this, notably in the western parts of Africa, the French colonial administration separated a 'Black' sub-Saharan from a 'White' and 'Mediterranean' northern Africa. ${ }^{42}$ This occurred for many geopolitical reasons and sedimented in disconnected territorial conglomerates of French West and French Equatorial Africa to the south of the great desert and the departments, military districts and protectorates on the northern side. This separation has had important perceptual and conceptual effects in politics, media and academia until today. Consequently, African studies in the Western academic system still very often concentrate only on the parts of the continent south of the Sahara, while Maghreb studies remained a strong, separate French predilection. But also the

\footnotetext{
38 Koepf, Tobias/Sold, Katrin: Transregionale Verflechtungen zwischen Maghreb und Sahel, in: Wippel/ Fischer-Tahir (eds.): Meta-Geographien (see footnote 2), pp. 325-345.

39 The author of this essay has himself contributed to this new field of research, first at the Zentrum Moderner Orient in Berlin (2000-2003) and then at the University of Erlangen (2003-2008). This materialised in the edited volume Marfaing, Laurence/Wippel, Steffen (eds.): Les relations transsahariennes à l'époque contemporaine. Un espace en constante mutation, Karthala/ZMO, Paris/Berlin 2004, which conceived the trans-Saharan field as a "space in constant mutation". A second book (Wippel: Wirtschaft, see footnote 2) linking considerations of space with economics and politics, from which many of the present explanations draw, was the main result of the subsequent habilitation project.

40 Cf. again Lewis/Wigen: Myth (see footnote 12).

41 Said, Edward W.: Orientalism, Routledge \& Paul, London et al. 1978.

42 Lydon, Ghislaine: Saharan Oceans and Bridges. Barriers and Divides in Africa's Historiographical Landscape, in: The Journal of African History 56 (2015), No. 1, pp. 3-22.
} 
Maghreb shows fuzzy and historically and politically varying contours between the Red Sea and the Atlantic Ocean, the Mediterranean and the Sahel. ${ }^{43}$ Parallel to that, invoking ethno-linguistic criteria, the competing construct of a greater Berber area (Tamazgha) emerged, which extends even beyond the Sahara. ${ }^{44}$

After North Africa was increasingly separated from the rest of the African continent, more and more it has been subsumed under another deeply ingrained metageographical region: the 'Near' or 'Middle East', now enlarged to the 'Middle East and North Africa' (MENA) in global politics and international organisations, but sometimes also the 'Arab(-Islamic) world'. As regards the conventional landmasses, this world region cuts North Africa and West Asia away from the respective African and Asian continents to which they had been traditionally assigned. However, the region is also characterised by a multitude of designations, which, like its geographical delimitation, vary considerably in time and language. ${ }^{45}$ Indeed, behind these regional terms, we find again Western geostrategic interests of the late 19th and early 20th century. They were primarily coined in political chancelleries to express political aspirations in the areas between the Mediterranean, Central Asia and India. Various attributes, from more natural and sociocultural (ethnic, linguistic and religious) characteristics to political and economic ones (like rentier capitalism and authoritarian regimes), have been used in the attempt to define the region. ${ }^{46}$ Similar problems of clear definition arise for the "Arab world' ${ }^{47}$ Again, the multiplicity of designations and their vague definitions contradict the fundamental character often attributed to this part of the world. Here, too, entanglements, processes of exchange and institutionalisations often unfold in quite different regional contexts, just as they do across the Sahara.

In the wake of exploring expeditions and territorial conquest, French colonial scholars definitely showed interest from a historical perspective in such Sahara-crossing connections, like caravan routes used by traders, pilgrims and scholars, but also

\footnotetext{
43 Wippel: Wirtschaft (see footnote 2).

${ }^{44}$ Pfeifer, Kristin: „Wir sind keine Araber!“. Amazighische Identitätskonstruktion in Marokko, transcript, Bielefeld 2015, pp. $92 \mathrm{ff}$.

${ }^{45}$ E.g. Scheffler, Thomas: "Fertile Crescent", "Orient", "Middle East". The Changing Maps of Southwest Asia, in: European Review of History/Revue européenne d'Histoire 10 (1993), No. 2, pp. 253-272; Escher, Anton: Die geographische Gestaltung des Begriffs Orient im 20. Jahrhundert, in: Schnepel, Burkhard/ Brands, Gunnar/Schönig, Hanne (eds.): Orient - Orientalistik - Orientalismus. Geschichte und Aktualität einer Debatte, transcript, Bielefeld 2011, pp. 123-149; Bonine, Michael E./Amanat, Abbas/Gasper, Michael Ezekiel (eds.): Is There a Middle East? The Evolution of a Geopolitical Concept, Stanford UP, Stanford, CA 2012.

${ }^{46}$ E.g. Büttner, Friedemann/Scholz, Fred: Islamisch-orientalische Welt. Kulturtradition und Unterentwicklung, in: Nohlen, Dieter/Nuscheler, Franz (eds.): Handbuch der Dritten Welt. Vol. 6, Nordafrika und Naher Osten, Dietz, Bonn 1993, pp. 16-66.

47 Cf. also Popp, Herbert: Die Arabische Welt - was ist das eigentlich?, in: Meyer, Günter (ed.): Die Arabische Welt im Spiegel der Kulturgeographie, Zentrum für Forschung zur Arabischen Welt, Mainz 2004, pp. 8-29; Escher, Anton: Arabische Welt, Islamische Welt oder Orient? Ein Plädoyer für „Arabische Welt“ und „Islamische Welt“ gegen „Orient“, in: Praxis Geographie 35 (2005), No. 3, pp. 4-11; Culcasi, Karen: Cartographies of Supranationalism. Creating and Silencing Territories in the "Arab Homeland", in: Political Geography 30 (2011), No. 8, pp. 417-428.
} 
issues like local and imperial conflicts and rule. ${ }^{48}$ Already Théodore Monod-and later I. William Zartman, and more recently again Marc Côte-asked whether the Sahara constitutes a barrier or a bridge. ${ }^{49}$ The term 'trans-Saharan' gained special prominence with a number of desert-crossing road and railway projects. A second interest came up during the independence period when the young North African states, first, appropriated historical research to legitimise territorial claims and, then, started to intensify their political relations with sub-Saharan countries, competing for influence and power on the continent. Nevertheless, relations and links across the Sahara remained an underrepresented field. European popular literature, in contrast, until recently emphasised the emptiness and uncrossability of the Sahara, but also loved to plunge in the desert's mysticism and exoticism (see also below).

New academic interest in the Sahara and trans-Saharan connections only emerged again in the late 1990s due to specific geopolitical circumstances. First, this was in a context of a resurgent, this time mainly economic, interest of North African states in sub-Saharan Africa triggered by great disappointment in cooperation with Europe and within the Arab world. Libya went ahead and later notably Morocco followed in pushing economic collaboration. Much more important for this growing attention, especially in European but also in Maghrebian politics, media and academia, were trans-Saharan waves of 'illegal', 'clandestine' or 'irregular' migration (see below). Sub-Saharan workers already present in the Maghreb and other people departing from countries in the Sahel and further south started to cross the Mediterranean in the early 1990s. The progressive closure of the EU's borders has forced many migrants to stay in North Africa, while countries like Morocco are becoming (again) destinations for work, study and residence in their own right. Terrorism, in particular Islamist violence, connected with banditry, trafficking and kidnapping, are other phenomena in the seamlessly interwoven Sahara, Sahel and Maghreb regions that have attracted much public and academic attention. With these recent developments, popular characterisation, too, very often turned to portraying the Sahara and its fringes as obscure, dangerous and threatening terrain. Last but not least, conceptual developments, instigated by the wider spatial turn, also contributed very much to the renewed academic interest in trans-Saharan connections.

This has led to a multitude of academic and semi-academic publications appearing on the market. They encompass a noteworthy number of important monographs and edited volumes (including some special journal issues) that cover specific aspects and corridors, as well as broader evolutions. ${ }^{50}$ Other valuable results have been released

\footnotetext{
48 Cf. overview in McDougall, Ann E.: Research in Saharan History. Review Article, in: Journal of African History 39 (1998), No. 3, pp. 467-480.

49 Monod, Théodore: Le Sahara. Barrière où trait d'union, Causerie au Rotary Club de Dakar, 20 février 1937, unpublished lecture, quoted in Marfaing/Wippel: Relations (see footnote 39), p. 7; Zartman, I. William: The Sahara. Bridge or Barrier, in: International Conciliation 541 (1963), pp. 1-62; Côte, Marc: Le Sahara. Barrière ou pont? Presses Universitaires de Provence, Aix-en-Provence 2014.

50 Webb, James L.A., Jr.: Desert Frontier. Ecological and Economic Change Along the Western Sahel, 1600-1850, Wisconsin UP, London 1995, among other writings, set the ball rolling when he discussed the delimitation of the Sahara in physical vs. human terms. While Abou El Farah, Yahia/Akmir, Abdelouahed/ Beni Azza, Abdelmalek: La présence marocaine en Afrique de l'Ouest. Cas du Sénégal, du Mali et de la Côte d'Ivoire, Institut des Etudes Africaines, Université Mohamed V-Soussi, Rabat 1997 investigated the often underestimated establishment of Moroccans in West African countries; Grégoire, Emmanuel:
} 
by research institutes, think tanks and individual scholars in innumerable working papers, nowadays mostly freely available on the World Wide Web. Whereas, under the pressure to publish in peer-reviewed journals, most research is now published as journal articles, some more new books have been printed in the second half of the decade — six of them will be reviewed on the following pages. ${ }^{51}$

\section{The Multiple Dimensions of a Highly Differentiated Maghreb- Sahara-Sahel Area}

Trans-Saharan relations are notably a predilection of French-speaking and Frenchwriting scholars. In France in 2018, the trans-Saharan perspective even entered the curriculum for the nationwide agrégation examinations in geography. ${ }^{52}$ Accordingly, three books with identical titles were published for students to use to prepare for the examinations, which, from different angles, want to give a comprehensive picture of developments in the Sahara and across it as well as of their wider embeddings; two of them will be reviewed in the following section, both edited by well-known geographers. ${ }^{53}$

Touaregs du Niger. Le destin d'un mythe, Karthala, Paris 1999, and Brachet, Julien: Migrations transsahariennes. Vers un désert cosmopolite et morcelé (Niger), Croquant, Bellecombe-en-Bauges 2009 focused on the re-establishing Eastern Saharan axis between Chad, Niger and Libya; and Pliez, Olivier: Les cités du désert. Des villes sahariennes aux saharatowns, IRD/PU du Mirail, Marseille/Toulouse 2005 studied the growth and decline of Saharan towns, notably in Libya. Among outstanding works on history, we find the dissertations of Aouad-Badoual, Rita: Les incidences de la colonisation française sur les relations entre le Maroc et l'Afrique Noire (c. 1875-1935), PhD thesis, Université de Provence (Aix-Marseille I), Aix-enProvence 1994; and Lydon, Ghislaine: On Trans-Saharan Trails. Islamic Law, Trade Networks, and CrossCultural Exchange in Nineteenth-Century Western Africa, Cambridge UP, Cambridge 2009 on territorialisation and regionalisation processes in the Sahara. Scheele, Judith: Smugglers and Saints of the Sahara. Regional Connectivity in the Twentieth Century, Cambridge UP, Cambridge 2012 provided another important contribution with her book on life in the borderlands between Algeria and Mali. Grégoire, Emmanuel/ Schmitz, Jean (eds.): Afrique noire et monde arabe. Continuités et ruptures (autrepart. Les Cahiers des sciences humaines, nouvelle série 16), Editions de l'Aube/IRD, La Tour d'Aigues/Bondy 2000; and Marfaing/Wippel: Relations (see footnote 39) brought together first comprehensive results of trans-Saharan research and focused on continuously reconfiguring trans-Saharan relations; McDougall, James/Scheele, Judith (eds.): Saharan Frontiers. Space and Mobility in Northwest Africa, Indiana UP, Bloomington, IN 2012 gathered more advanced studies on mobilities within and into the Sahara as a highly differentiated space; and Côte: Sahara (see footnote 49) drew again an encompassing picture of historical and contemporary developments in and around the Sahara. Finally, Grégoire, Emmanuel (ed.): Géopolitique du Sahel et du Sahara (Hérodote. Revue de géographie et de géopolitique 172), Paris 2019 covers current geopolitics of the Sahara and the Sahel.

51 This review still remains exemplary, because not all works of interest have been available: namely, Anglo-American publishers deemed publications that are a little bit older no longer worth reviewing, while most French publishing houses did not even answer requests for copies; some of them could be reviewed only because they were available directly from authors and editors. Thanks to them!.

52 This is a highly selective competition for professors' positions in the higher education system, mainly for the upper classes of secondary schools and for preparatory classes at university level for the national Grandes Ecoles.

53 The third book is Andrieu, Julien (ed.): L'Afrique. Du Sahel et du Sahara à la Méditerranée, Ellipses, Paris 2017. 
Armelle Choplin, Nora Mareï and Olivier Pliez coordinated the first book, "L'Afrique du Sahel et du Sahara à la Méditerranée" ${ }^{54}$, which gathers an interdisciplinary team of authors not only from the field of geography, but also political scientists, social anthropologists, historians and the like. A large introductory part, however, still presents separately the three sub-regions that make up the title. The volume aims at opening different ways and directions to reflect "on the moving, immense and complex regional space" (p. [9]). ${ }^{55}$ According to the editors, all its sub-regions can be considered margins, far away from the big centres of decisionmaking and consumption. Yet, they intend to reorientate perspectives on an area that, in fact, is fully anchored in the world and even at the centre of many current evolutions and-following a French academic tradition-should be regarded as a newly establishing geopolitical hinge. Therefore, to study this area, they pursue a multiscalar and relational approach, and a special chapter deals with the deconstruction of the existing heritage of geographical knowledge, thereby explicitly attacking seemingly fixed metageographies. Instead, they emphasise the vague definitions, the dynamics and plasticity of the regions under study (esp. pp. $88 \mathrm{f}$.). The close entanglements with vast hinterlands and the fact of constituting multiple regional interfaces instead of exhibiting unidirectional orientations are repeatedly underlined. All three sub-areas are regarded as intimately interconnected and as still forming today a "coherent ensemble of exchanges" (p. 35), where complementarities and connections interplay with discontinuities and fractures.

Other chapters tackle the natural environment, with topics such as climate hazards, advancing desertification and changing pastoralism (including a case study of the Lake Chad region). They examine economic and territorial recompositions that involve strong extraterritorial economic interests. Mining and the oil industry; the globalisation and transformation of trading places in North Africa, with emerging links as far as China; rural development and food security, including a case study of cannabis farming in northern Morocco; and the establishment of road connections across the "Mediterranean-Saharian-Sahelian region" feature prominently in this part of the book.

A further chapter analyses human and material circulation and mobility between the Sahara's two 'shores'. In particular, the trans-Saharan region is experiencing a "new geography of migration governance" (p. 121) in which three types of borders have emerged: the clear-cut territorial borders of the Schengen area; the North and West African coasts as a buffer area; and the vast Saharan-Sahelian space with increasing control and obstruction of outgoing, but also of internal mobilities. The chapter also includes consideration of the rapid and high urbanisation of the Sahara as well as a number of case studies: this notably points to the emergence of Souks Libya in the 1970s, when Libya was a pioneer in the contemporary trans-Saharan migration complex. These markets, where subsidised Libyan products were sold, extended from Algeria through Chad and Sudan to Egypt. They faded away in the 1990s, partly replaced by the Souks Dubai for Far Eastern products transiting

\footnotetext{
54 Choplin, Armelle/Mareï, Nora/Pliez, Olivier (eds.): L'Afrique du Sahel et du Sahara à la Méditerranée, Atlande, Neuilly 2017.

55 All quotes and semi-quotes in the following have been translated by the author.
} 
through Arab Gulf countries. Cairo as a re-emerging crossroads at the northern end of the Nilotic corridor, but also a dead end for further migration; the transformations experienced by the Nigerien oasis of Dirkou under current conditions of transSaharan migration; and the experiences of Burkinabé migrants in Italy add further dimensions to this part of the volume.

Finally, a chapter on tensions merges aspects of history, identity and geopolitics in an area never controlled or dominated by one single power, but nonetheless experiencing a joint history and common geopolitical challenges. In particular, the break between North and sub-Saharan Africa that developed in colonial times and was reinforced by upcoming nationalisms is mentioned (p. 168). Especially in the Maghreb countries, 'Africa' still often designates the 'Other' and correlates with widespread discrimination. Nevertheless, anti-discriminatory mobilisation and a certain consciousness of one's own "Africanicity" now have started to emerge. Overall, besides long-term evolutions and fluctuations of exchange, this part covers critical issues like the Western Sahara question; decentralisation efforts and the Touareg problem in Mali; the repercussions of the 2011 North African 'springs', notably in secondary and peripheral cities; the geopolitics of terrorist attacks in Tunisia and the Sahel; and trade networks in the borderlands of northern Mali and southern Algeria. Finally, it studies Khartoum as a city of refuge for persons displaced in Sudan's internal wars, where attempts at dealing with ethnic diversity have failed.

The second volume, edited by Brigitte Dumortier, "L'Afrique. Du Sahel et du Sahara à la Méditerranée" 56 , includes mostly geographers as authors. Its introduction gives an overview of the different parts of the book, rather than a conceptual setting for the overall volume. Subsequently, the first part of the volume examines resources, demography and development, cultural characteristics and health issues. The area under study is more or less presented as given. While Dumortier starts with an extensive discussion of bioclimatic regional definitions and "irremediable" fuzzy delimitations, she also points out that we are dealing with a spatial continuum between the Maghreb and the Sahel. The region under study is characterised by its dialectic of unity and diversity. Nonetheless, in detail, the editor still presents a strong division of the wider area: the Maghreb states are considered part of the Mediterranean world, which contrasts with the emphasis on North Africa's belonging to the Arab geocultural ensemble; however, the statement that language is "a factor of unity" in North Africa (p. 17) is difficult in view of the strong Amazigh (Berber) element, a position the author herself focuses on later in the same volume (pp. $61 \mathrm{ff}$.). The Sahara is considered a more or less empty space in between; according to Dumortier, it is to be conceived less as a break than as a link, but in fact oscillating between the two, depending on historical circumstances. The Sahel is regarded as a transition zone and interface between North and 'Black' Africa.

In contrast, part II succeeds in demonstrating existing entanglements and antagonistic dynamics of integration and fragmentation. The first chapter does this from a perspective of human and material flows across the Sahara, their itineraries and the networks behind. The second starts with institutional integration, but also extends to other, mostly territorial issues, like interstate conflicts, demands for autonomy,

${ }^{56}$ Dumortier, Brigitte (ed.): L'Afrique. Du Sahel et du Sahara à la Méditerranée, Colin, Paris 2017. 
Jihadist dangers and democratic transition, offering a wider geopolitical reading of the desert and its transitional borderlands. Particularly (irregular) migration is considered as a convergence between the Maghrebian and Sahelian peripheries, with important repercussions for Euro-Maghrebian relationships. Yet, Europe is not the exclusive destination of trans-Saharan migrants, and the Maghreb not only a transit zone. (Mostly informal) trade is going in the opposite direction and largely resembles former caravan trade networks without being simply continuity. The author of this chapter, Ali Bensaâd, considers these movements part of a globalisation "from below" and "from the margins" (p. 111). Like the editor (p. 11f.), he identifies the comeback of a historical "meridional" (North-South orientated) working of the whole area and a reinforcement of trans-Saharan axes in contrast to the zonal (or laminary) spatial organisation imposed under colonial rule, which made the Sahara a "hiatus" (p. 116). Re-emerging flows have revitalised former crossroads in and around the Sahara and restored the desert's role as a space of transit and exchange.

The third part analyses the manifold mutations the region is undergoing, notably the (uneven) impact of globalisation: this relates to the development of cities, the role of ports and the importance of rivers and rural development. Part IV finally presents two case studies, one showing Chad's national diversity, fractures and impediments to development, whereas the other concentrates on local dynamics and social rivalries in the M'zab valley in the northern Algerian Sahara.

Effectively, the two books lend themselves to comparative reading: in some respects overlapping, in others complementary, both present a good state-of-the-art compilation of current academic knowledge and help readers gain more than a first glimpse of the complex and entangled past and present of the transregional MaghrebSahara-Sahel space and its wider connections. Concerning North Africa, both volumes primarily focus on the core Maghreb countries as a French stomping ground, whereas Libya and Egypt—despite some case studies—remain rather underexplored. The Sahelian parts extend from Mauritania to Sudan, but also include the Horn of Africa in Dumortier's publication. Whereas Choplin et al. gather nearly triple the number of authors, most of them well-established specialists on the Sahara and adjacent areas, Dumortier's edited volume contains fewer, yet more prominent professors in geography. It has a clearer arrangement of chapters and seems more consistent in covering various aspects of the area under study. In contrast, the first publication is more academic, contains more case studies and is more analytic and conceptual; it also points more explicitly to the socio-constructivist background of an appropriate reading of developments in the area, so difficult to define. Dumortier has the advantage of higher printing quality and more and better maps; for each chapter, authors are clearly defined, whereas the first book hides authors' responsibility for each subchapter in their short CVs. Bibliographical references, added to each chapter in Dumortier's book and very comprehensive, including a glossary, at the end of the other one, are nearly exclusively to publications in French, ignoring some essential contributions in other languages. ${ }^{57}$ However, we have to keep in mind that both

57 E.g. Choplin et al.: Afrique (see footnote 54) give only eight English publications among hundreds of French ones. 
publications were prepared as textbooks for the examination of advanced French teachers and not for academic specialists.

This also applies to the third publication, which offers another format as a primarily non-academic kind of publication. With "Sahara, mondes connectés" 58 , Titouan Lamazou presents the catalogue of an exhibition at the Museum for African, Oceanian and Amerindian Arts (MAAOA) in Marseille in 2019, published together with the Institut de Recherche pour le Développement (IRD). The IRD has been putting the Saharan space in the centre of its multidisciplinary research for several decades now. For said exhibition on the occasion of its 75th anniversary, it has associated with the MAAOA. An artist, Titouan Lamazou, and a historian, Charles Grémont (IRD Marseille), collaborated to "find a balance between arts and humanities" (p. [11]) and to "decipher stereotypes and established ideas" (p. [5]). They wanted to "overcome simplistic visions" (p. 19) that associate the Sahara either, until the early 2000s, with purity, spirituality and adventurism, or, nowadays, with more sombre representations linked to chaos and danger.

As the catalogue intends to offer a synthesis of long-lasting research activities to a broader public (p. 23), interventions come mostly from a multidisciplinary team of established scholars working on the Sahara, most of whom we already met as authors in the two previous books. Like the many illustrations showing exhibition objects, old photographs and artistic works, the academic texts primarily cover the Western and Central Sahara. The Sahara is not considered an empty area, separating two different Africas, but, first of all, a millennium-old space of life and passage (p. [9]) that shows multiple and diverse connections and that experiences continuous change. Places are considered as (sometimes ephemeral) moments of these connections: as meeting places, stages of travel, market places, Bedouin, military and refugee camps, oases and cities.

The publication starts with an interview with the editor and a common introductory contribution by Sophie Caratini, Charles Grémont, Céline Lesourd and Olivier Schinz, who sketch a conceptual framework and give an overview of the following book sections, arranged in accordance with the main exhibition cabinets. The more than 20 articles also include childhood memories (e.g. of a former nomad and a herdsman) and reports of life experiences (from an Afro-American traveller in the 19th century to a contemporary Mauritanian businesswoman and role model), poems, including markedly political ones, and extracts from historic travel accounts. The first section, "Following the Traces", aims to share experiences of emptiness, destabilisation and aridity and contrast these with the numerous and long-lasting internal and external connections of the region. Hence, trajectories of narration threads, transhumance, voyages, trade exchange, pilgrimage, bellicose expeditions, diplomatic missions and all forms of migration, which have structured the Sahara since antiquity, are a leitmotif of the following parts of the catalogue. The topics move from "Nomadising" to "Crossing" and "Stopping": this relates to flows halting at oases that constitute nodal points in networks, but also to the emergence and connections of past and present "Saharatowns". "Digging the Ground" covers the mining and oil industries, including places of informal gold extraction. "Fighting

58 Lamazou, Titouan (ed.): Sahara, mondes connectés, Gallimard, Paris 2019. 
and Dialoguing" revolves around issues of military and spiritual power and the establishment of states: this is reflected in the Touareg arts of poetry and warfare, in Islamic jurisprudence and conflict resolution in 17th-century Touat in southern Algeria, as well as by Jihadists and smugglers straying in the southern Libyan borderlands. Finally, "Transmitting" is a section on the circulation of news, ideas and knowledge, with another focus on poetry, whereas "Travelling" looks at explorers, scholars and tourists, together with migration and circulation in the Central Sahara; memories, ruins and again poems fall under the category of "Mirages", including accounts of vain attempts to control nomads from French colonial times to French military interventions today.

The volume concludes with a list of exhibits and a short bibliography for further reading. The Sahara is at the centre of this publication, but flows and connections not only within, but also far beyond the desert give it a transregional perspective, too. The texts are (partly perhaps too) short, but competently written, and leave readers with the desire for more information. However, chapter and section titles do not always immediately unlock the following contents to the reader.

\section{The Complexity of Trans-Saharan (and Wider) Migration Systems}

The previously reviewed publications already tackled diverse movements of people, including irregular migration. Publishing on this topic started in the early $2000 \mathrm{~s}$ with a commissioned study by a team of authors on migration to and through Morocco. ${ }^{59}$ Subsequently, besides the general works on trans-Saharan connections, a large number of works has been rapidly produced. ${ }^{60}$ They deal with a wide range of issues, including permanently changing and shifting migration routes, hubs and networks. Also addressed have been political action strategies, including the expansion of European territorial control mechanisms to the Maghreb and the Sahel zone, contrasting with studies of the multitude of involved actors and everyday experiences of migrants. ${ }^{61}$ In 2016, two other volumes examined migration that is more or less 'irregular', as it is often difficult to distinguish between more formal forms that abide

\footnotetext{
59 Barros, Lucile et al.: L'immigration irrégulière subsaharienne à travers et vers le Maroc, Bureau International du Travail, Genève 2002.

60 E.g. Bredeloup, Sylvie/Pliez, Olivier (eds.): Migrations entre les deux rives du Sahara (autrepart. Les Cahiers des sciences humaines 36), Colin/IRD, Paris/Bondy 2005; Nyberg Sørensen, Ninna (ed.): Mediterranean Transit Migration, Danish Institute for International Studies, Copenhagen 2006; de Haas, Hein: The Myth of Invasion. Irregular Migration from West Africa to the Maghreb and the European Union, International Migration Institute, University of Oxford, Oxford 2007, URL: <www.heindehaas. com/Publications/de\%20Haas\%202007\%20Irregular\%20migration\%20from\%20West\%20Africa\%20. pdf> [accessed: 21 November 2007]; Peraldi, Michel (ed.): D'une Afrique à l'autre. Migrations subsahariennes au Maroc, CJB/Karthala/CISS, Rabat et al. 2011.

61 E.g. Alioua, Mehdi: L'étape marocaine des transmigrants subsahariens en route vers l'Europe. L'épreuve de la construction des réseaux et de leurs territoires, $\mathrm{PhD}$ thesis, Université Toulouse le Mirail-Toulouse II, 2011; Mouna, Khalid (ed.): Espace imaginé, espace vécu et espace négocié. Parcours croisés des migrations espagnoles et subsahariennes à Tanger, AMERM, Rabat 2016, URL: <http://amerm.ma/wp-content/uploads/2016/05/Espace-imagin\%C3\%A9-espace-v\%C3\%A9cu-etespace-n\%C3\%A9goci\%C3\%A9-Mouna-Khalid.pdf> [accessed: 28 September 2016].
} 
by legal rules and the more clandestine ones. Both publications address not only trans-Saharan migration per se, but also the wider migration complex, demonstrating the greater implications and entanglements of the phenomenon.

"Revisiting Moroccan Migrations", edited by Mohamed Berriane, Hein de Haas and Katharina Natter ${ }^{62}$, focuses on a specific country's experiences with immigration and emigration. The authors of the introduction and the following six chapters are mainly geographers and sociologists. Due to the international mix of authors, this volume includes not only Anglophone literature, but also a considerable number of references, e.g. in French and German. According to the editors' introduction, the book seeks to promote a dialogue between theory and empirical research. On the one hand, it intends to challenge established views of international migration (p. 12); on the other hand, it wants to explore a number of understudied aspects of the phenomenon. In particular, it endeavours to overcome the conceptual divide between 'receiving' countries, mostly in the Global North, and of 'sending' countries in the South. In contrast, while it is true that emigration from Morocco still dominates, the Kingdom is increasingly developing into a country of transit and, since the 2000s, also into an important destination for international migration. This requires the Moroccan state to deal with a number of hitherto less relevant political, social and cultural issues. Beyond simplistic push-and-pull models, people's changing perceptions, aspirations and intentions make up a central theme throughout the entire volume, which also demonstrates how toughened restrictions erected by European governments instigate a preference for prolonged or permanent settlement (as opposed to circular migration) and a series of substitution effects (as to illegality, timing and destinations). Likewise, notions such as 'transit' or 'trapped' migrants prove to be relative. In addition to Africans from south of the Sahara, Filipina housemaids, European job seekers and pensioners, Chinese traders and Middle Eastern refugees also have started to long for Morocco. With that, migration not only goes in a South-North direction, but also occurs in South-South contexts and even develops from North to South. This shows how difficult it is to distinguish clearly separated regional migration complexes, especially as Morocco positions itself in many respects as an interface between Europe and Africa, the Sahara and the Mediterranean.

The first three chapters focus on Moroccans living abroad, mainly in Europe or aspiring to leave for it. This part demonstrates how emigrant communities acquire political voice by (and not alternatively to) exiting and how relations with the Moroccan state have changed in the long-term migration process. It also covers legal language obstacles established by the German state for marriage migration, leading to selection according to educational and financial backgrounds and making language schools gatekeepers. It finally studies changing aspirations for migration on the part of Moroccans at home in the aftermath of the 2008 economic crisis that affected main destination countries in Europe.

62 Berriane, Mohamed/de Haas, Hein/Natter, Katharina (eds.): Revisiting Moroccan Migrations, Routledge, London/New York 2016. The contributions to the volume had previously been published in a special issue of The Journal of North African Studies 40 (2015), No. 4. 
In accordance with the overall theme of my essay, I turn my attention to the two chapters that explicitly deal with trans-Saharan migration. The first is on students, who, contrary to prevailing ideas, form part of highly skilled emigration from subSaharan Africa. Student migration grew considerably since the 1970s in the context of Morocco's intensifying African policy. According to Johara Berriane, three factors are crucial for the prospective students' decisions to move to Morocco: their initial aspirations to emigrate; growing up in cultures that value migration; and the existence of transregional social networks. However, once arrived, everyday experiences of 'otherness', as well as disenchantment with an environment that is much less 'Islamic' than expected, lead to withdrawal into cosmopolitan sub-Saharan spaces and the development of a pronounced black identity or national consciousness, among other things. Initially, Morocco is often considered only a first step in longer-term plans to continue studies or to work in other countries afterwards. Nonetheless, due to geopolitical and personal circumstances, students gradually start to settle in Morocco. Often they find work in sectors like media and telecommunication, where they benefit from their French language skills and sometimes even act as middlemen for their Moroccan employers in their countries of origin. In fact, not only in this case, it has become difficult to separate student, labour and refugee migration, as one and the same person may adopt several roles simultaneously or oscillate between them.

The second article tackles the recent changes in Moroccan immigration policy in a context of geopolitical reorientations. Myriam Cherti and Michael Collyer observe a shift from the reactive, security-concerned approach under European influence in the last decade, to more autonomous, proactive and humanitarian policies in the current one. This is an adaptation to changing migratory realities and domestic political pressures, including the mobilisation of civil society, but at the same time reflects wider geostrategic considerations at national and international levels, namely a concern for international reputation against the background of global human rights discourses and, again, the country's growing political, economic and cultural links with sub-Saharan Africa. Conceptually, the authors link this move to ideas of a country "thinking itself" and "geopolitical culture" (p. 88). The book concludes with a chapter that considers the settlement of French citizens in Morocco and their socio-cultural adaptation strategies.

Belachew Gebrewold and Tendayi Bloom are the editors of the second volume, "Understanding Migrant Decisions. From Sub-Saharan Africa to the Mediterranean Region"63, which is based on papers for an international conference in 2014, just before the much-discussed arrival of large numbers of migrants in Central and Northern Europe. Together with an interdisciplinary team of authors responsible for eleven chapters, they concentrate on individual, initial-stage decision-making processes on whether, where and how to migrate and on subsequent decisions to move onwards, remain or return. Namely, the non-linearity and adaptability of decisions constitute a "core concept" of the publication (p. 18). The papers endeavour to find a large variety of reasons for these decisions. Above all, it is impossible to clearly distinguish between economic motives and decisions based on threats to physical security,

63 Gebrewold, Belachew/Bloom, Tendayi (eds.): Understanding Migrant Decisions. From Sub-Saharan Africa to the Mediterranean Region, Routledge, London/New York 2016. 
as European authorities would like to do. In particular, the authors want to study the effects of troubles in North Africa and the economic downturn in Southern Europe in the early $2010 \mathrm{~s}$, but at the same time they counter too simplistic reductions of changing migration patterns to these two evolutions. However, changes in the Mediterranean region strongly interact with those in (widely overlapping) regions such as Africa, Asia, Europe and the Middle East. The book has an analytical focus on those staying in or transiting North Africa, but also on countries like Turkey and Spain.

Despite the self-imposed demands, however, the first two book chapters have a strong abstract macro-perspective instead of empirically focusing on individual migrants' motivations and decisions. The first chapter analyses migration from the Horn of Africa to Europe in a context of state collapse, Islamic fundamentalism and fatal poverty in Somalia. It focuses on changing conditions on the way to the North, namely in Libya and Egypt and along Israel's border, which affect decisions to migrate, notably on household levels. The construction of a rhetoric of "crisis"-well before 2015-is at the centre of the second chapter. The background is the shift of trans-Saharan migration (and the joining of Syrian refugees) back to the maritime route from Libya after the country's disintegration. Chapter 3 turns to Nigerien pastoralists. Their strategies of adapting to drought gradually shifted from pre-colonial transhumance to water-richer areas in the south to dependence on temporary rural-tourban migration in independent Niger and to responses to Libyan calls for workforce immigration before the recent turmoil in the neighbouring country 'trapped' many families in their places of origin. In chapter 4, Delf Rothe and Mariam Salehi make a strong effort to link empirical findings with conceptual insights. By distancing themselves from macro-approaches and quantitative research, they study processes affecting West African migrants' decision-making in Germany, whom they consider purposefully acting subjects rather than externally determined, reacting objects. In their relational concept of autonomy, they emphasise emergent causalities, the role of cascading events and the constant and complex interplay of structural factors and individual agency. Another more macro-oriented contribution regards privatisation, e.g. of detention facilities and transport controls, as a central element in the externalisation of border management. This takes decisions largely out of the hands of both states and migrants and at the same time triggers the emergence of another private migration industry specialised in helping people circumvent imposed barriers to moving.

Second-step decisions made when people are on the move are at the centre of the articles in the second half of the book. According to chapter 6, the reversal of economic developments in Greece as compared with Turkey, the rise of Greek xenophobia and the securitisation of land and sea borders effected a diversification and redirection of migration patterns in the Aegean, already before 2015. Besides some returns from Greece to Turkey, a tendency to stay in Turkey due to improving business opportunities or to reorient further migration plans towards destinations like China or Dubai, as well as the decision to continue from Greece via the Balkans to the North, was on the horizon. The next paper refers back to a topic already mentioned in the previously presented publication: here, Silja Weyel looks at West African employees in Moroccan call centres working for companies in France. 
This explicit work migration is based on emerging job opportunities and enables African students to finance their studies. Chapter 8 concentrates on often-neglected gender-related aspects of Ethiopian labour migration to Middle Eastern countries. The article shows considerable differences between women and men in the choice of destinations, the formality of travel, occupations et cetera. Overall, women seem to have lesser negative perceptions of their stays abroad, but lesser positive experiences of reintegration back home than men.

Sub-Saharan migrants' experiences on the Mediterranean's northern side, in Barcelona, are starting points for two further micro-analyses: Chapter 9 shows how migrants' decision-making is increasingly linked to struggles for the 'right to the city'. In the case of self-organised scrap metal collection by the sub-Saharan community, the forced clearing of their headquarters was a "focusing event" that shaped irregular migrants' experiences. The final self-account of a Ghanaian migrant shows how, in migrants' countries of origin, imaginings of opportunities in Europe are misleading. He founded an NGO that, among other things, shoots videos to enlighten people in Africa who are thinking of emigrating about the difficulties on the long way north and supports migrants in Spain who are planning to return. The book's conclusion adds a number of political recommendations.

\section{Autonomy and Connectivities of People and Places in the Inner Sahara}

Finally, Julien Brachet, a French geographer, and Judith Scheele, a German anthropologist, who already became prominent with their aforementioned works, published the most recent book, "The Value of Disorder. Autonomy, Prosperity, and Plunder in the Chadian Sahara" 64 . During fieldwork deep inside the Sahara in 2011/12, they endeavoured to decipher and explain an object of study that oscillates between a group of people, a place, and a territory, namely the Tubu-speakers in and around the oasis town of Faya (also known under its colonial name Largeau) in what today is northern Chad. The somewhat fuzzy research focus is not due to indecisiveness on the part of the two scholars, but to the local conditions of uncertainty, vagueness and contrariness of processes, structures and information.

The Tubu-predominantly an outsiders' designation-are not a well-defined group of people with persistent social hierarchies and substructures, but in fact comprise two (yet mutually comprehensible) language groups, open to entry and exit and in continuous inner flux. A rather vague "Tubu world" extends from the traditional core area to southern Libya and eastern Niger and as far as Sudan, Egypt and more central parts of Chad, not to forget today's wider diaspora. And Faya is not a place of long historical continuity, but a town made through a series of local military and political crises and of broader processes and events elsewhere. Again and again, it has been the object of avarice of more or less external powers-from the expanding Sanussiyya order in the late 19th century and Ottoman, Italian and

\footnotetext{
64 Brachet, Julien/Scheele, Judith: The Value of Disorder. Autonomy, Prosperity, and Plunder in the Chadian Sahara, Cambridge UP, Cambridge 2019.
} 
French imperialisms to the East-West conflict and Libya's rise and fall (chapter 1 and 2). The late and hesitant French colonial arrival turned Faya rapidly from a $z \bar{a}$ wiya (a religious school or retreat) into a zarība (military camp) (p. 62). However, the local population has little interest in its own past-a void the authors try to go into throughout their publication. They understand the northern Chadian region of Borkou as a "half-world" that exists only through its ambivalent position between proximity and fundamental opposition to its surrounding worlds (p. 21). Individuals quickly change sides and loyalties, also in family affairs. This is closely entangled with a strong desire for "negative liberty", i.e. freedom from any interference (p. 120), and comprehensive autonomy. Despite its close entanglements, Faya has always looked like a quite inaccessible and dangerous place from the outside; this has contributed to the Tubu's "unknowability" (p. 26) and "remoteness" outside the dominant perception (p. 5), but also corresponds to a feeling of exacerbated otherness and extreme vulnerability from the inside (p. 5, 7).

Local (generally unstable) modes of production have also been initiated mostly from outside (chapter 3 and 4): this is true of agricultural production, where the Sanussis introduced regular cultivation and property rules, whereas the locals are not keen to systematically irrigate their productive date yards. In trade, Faya is a regional commercial hub and acts as a border town, even if traditional caravan routes bypassed the oasis at a great distance. Yet, long-distance trade (sometimes from Egypt and as far as Congo) remains largely in the hands of outsiders, whereas petty trade is in the hands of women. Local men, in contrast, are more committed to levying their share of transiting commodities through brokerage, granting shelter and staging raids or from positions within the state administration; but most make their money far away from Faya.

For a long time, the Tubu were stereotyped as anarchists, savages, thieves, pagans and bad hosts; these images from outside also turned into self-characterisation. Therefore, the local social order and values are another focus of the present volume (chapter 5 and 6). Conspicuous consumption and a preference for waste while conveying the impression of abundance, are deemed to be core habits of the Tubu. Instead of forward-looking saving and purposeful investment, people only exceptionally engage in spectacular "coups" that become part of narratives of heroic personal success. Reciprocity and balanced exchange in social relations are emphatically denied, while the quick shuffling of wealth, immediate spending (or even bankruptcy) and unilateral gift-giving are glorified markers of individual generosity and sovereignty (for both men and women). This also reflects a life that is seen as notoriously unstable and unpredictable, in natural, social, economic and political terms. Yet, the state is not so far away as is often publicly voiced; notably, the Tubu endeavour (and succeed) in penetrating state institutions as much as possible, up to the national level. Even if it is more a rhetorical matter than one of fact, local narratives of "disorder" are statements of pride and involve a constant threat of violence and revolt. Raiding and theft are signs of courage and masculinity, tricking and duping are common even in close relationships.

Benefitting from a wide range of written sources, including official archives difficult to access, interviews and informal talks with many protagonists, the two authors demonstrate the extreme precariousness and rapid alterability of conditions in the 
Central Sahara. They also show the simultaneous translocal, transterritorial and transregional entanglements, extending between the Mediterranean and Central African regions, of the Saharan places and people under study. They present a very complex, challenging and ambitious publication, both in language and in results. Interesting would have been a short account of the two researchers' personal experience in this specific setting of permanent insecurity, ambiguity and fluidity of categories, structures and contexts, where foreigners "saw only what they were given to see" (p. 22). Obviously, most quotes are translated by the authors, but unfortunately the original languages are rarely mentioned. A few more illustrations would have been welcome to illustrate statements in the text.

\section{Synopsis and Outlook}

The publications presented in this essay demonstrate that trans-Saharan research is a wide and vital field of multidisciplinary research (with a certain preponderance of geographers). They stand against fixed regional metageographies and show a world in flux, where places and spaces are continuously reconfigured together with recurrent and profound social, political and economic changes. As in many other cases, the authors do not explicitly position themselves conceptually and methodologically in the field of transregional research or use the term 'transregional', even if in fact they treat transregional phenomena as defined above. Notwithstanding, they point to their socio-constructivist positions and try to overcome obsolete, misleading regional conceptions, as well as to counter socio-cultural stereotypes, which are often projected onto space. They also endeavour to bridge cleavages between context-sensitive, empirically based research, which is widespread in area studies, and nomothetic approaches common in the more 'systematic' disciplines. At the same time, they want to study hitherto neglected empirical aspects and contribute to refining existing theories, especially for the phenomenon of migration.

The books under review have a strong focus on regionalisations resulting from human and material flows, circulations, mobilities and networks like travels, tourism, pilgrimage and trade, expeditions, raids and assaults and, in particular, migration for educational and professional purposes along with flight from socio-economic and political circumstances. Yet, there is a complex interplay of structural push-andpull factors and constraints as well as of individual agency and subjective decisionmaking. "Spaces of flows" and "spaces of places"65 are only two sides of the same coin, as the erection, stabilisation and dismantling of territories and borders also come into the focus of analysis.

The 'region' under study does not abide by conventional regional delimitations and corresponding area studies, but remains difficult to define. Even if it seems to show, temporarily, a sort of (still vague) delimitation, its boundaries are immediately trespassed and transcended again. However, this also prevents us from relapsing into new spatial essentialisms and establishing a new 'area' in terms of durably canon-

\footnotetext{
65 A distinction made prominent by Manuel Castells in the first part of his trilogy: The Information Age.
} Economy, Society and Culture, Vol. 1: The Rise of the Network Society, Blackwell, Malden, MA 1996. 
ised studies. The trans-Saharan region extends, in essence, across the Maghreb (or North Africa), the Sahara and the Sahel, but often also largely overlaps and connects with another transregional area spanning the Mediterranean and can show further linkages extending far into what are conventionally regarded as the African and Asian continents. Neither the western nor the northern parts of Africa are distinct, segregated regions, but exhibit close connections across the Sahara, crossed either by foot, camel or lorry, yet also overflown by plane or circumnavigated by ship. Interaction and interdependence with Europe are important, but not exclusive, and sometimes even not decisive. The spatial and social continuums in these transregional complexes go hand in hand with a continuous shifting of routes, repeated changes of means of transport, actors, motives et cetera and constant transformations of living conditions and political circumstances that contribute to the repetitive regional reconfigurations.

The spatial contexts unfold on and across different spatial scales that increasingly blur and are quite difficult to separate, analytically as well as on the ground. The multiscalar perspectives include (trans)local, (trans)national and, in particular, (trans)regional dynamics, mobilities, networks and contexts. The books combine insights from deep inside and from outside the area under study here. The seeming contrast, e.g., between vast trans-Saharan migration complexes and the ostensibly small, confined inner-Saharan Tubu world is delusive, as the first simultaneously concentrates in very concrete places as well, such as refugee camps, call centres or universities, while the second deploys connections and presences extending between the Mediterranean and Central Africa.

The connectivities, life-worlds and spatial contextualisations are full of such ambivalences. The desert, the sea, but also national borders and group boundaries definitely act as separators and barriers as well as connectors, bridges and interfaces; however, the Sahara is not only a pure space of passage, but also constitutes an (interconnected) world of its own. Countries do not have a clear status as places of origin, transit or destination for transregional migration. The Maghreb-Sahara-Sahel complex exhibits common historical, cultural, economic and geopolitical traits and challenges versus diverging past and present trajectories. Mutual othering combines with partial senses of commonality. This coincides with the duality of proximity, openness and close entanglement versus remoteness, closure and inaccessibility. Hence, there is a perpetual dialectic of unity and diversity, integration and fragmentation. Economic and political turmoil constitutes important framework conditions. The uncertainty, unpredictability and instability of processes and structures in natural, social, economic and political terms and the constant revision of decisions and strategies are not only constitutive of Tubu society, but underly social life and conditions, according to the other publications, as well.

Finally, the researches presented in this text demonstrate the need to break out of linguistic parochialism (be it in English or French) to fully understand transSaharan entanglements and dynamics. Such transregional perspectives have started to be integrated, beyond the researcher community, at least occasionally, in the tertiary education system and in outreach activities such as museum exhibitions addressing a broader public. Hence, looking beyond established metageographies is a very beneficial undertaking and allows us to illuminate a plethora of phenomena 
that otherwise are easily ignored, while they constitute essential elements of global history and presence.

\section{Reviewed Literature}

- Berriane, Mohamed/de Haas, Hein/Natter, Katharina (eds.): Revisiting Moroccan Migrations, 125 pp., Routledge, London/New York 2016.

- Brachet, Julien/Scheele, Judith: The Value of Disorder. Autonomy, Prosperity, and Plunder in the Chadian Sahara, 348 pp., Cambridge UP, Cambridge 2019.

- Choplin, Armelle/Mareï, Nora/Pliez, Olivier (eds.): L'Afrique du Sahel et du Sahara à la Méditerranée, 240 pp., Atlande, Neuilly 2017.

- Dumortier, Brigitte (ed.): L'Afrique. Du Sahel et du Sahara à la Méditerranée, 288 pp., Colin, Paris 2017.

- Gebrewold, Belachew/Bloom, Tendayi (eds.): Understanding Migrant Decisions. From Sub-Saharan Africa to the Mediterranean Region, 244 pp., Routledge, London/New York 2016.

- Lamazou, Titouan (ed.): Sahara, mondes connectés, 196 pp., Gallimard, Paris 2019.

Funding Open Access funding enabled and organized by Projekt DEAL.

Open Access This article is licensed under a Creative Commons Attribution 4.0 International License, which permits use, sharing, adaptation, distribution and reproduction in any medium or format, as long as you give appropriate credit to the original author(s) and the source, provide a link to the Creative Commons licence, and indicate if changes were made. The images or other third party material in this article are included in the article's Creative Commons licence, unless indicated otherwise in a credit line to the material. If material is not included in the article's Creative Commons licence and your intended use is not permitted by statutory regulation or exceeds the permitted use, you will need to obtain permission directly from the copyright holder. To view a copy of this licence, visit http://creativecommons.org/licenses/by/4. $0 \%$.

Dr. rer. pol., Dr. habil. Steffen Wippel ist freier Wissenschaftler aus Berlin und assoziiertes Mitglied des Centrums für Nah- und Mittelost-Studien (CNMS) an der Philipps-Universität Marburg. Er forschte und lehrte an zahlreichen Universitäten und Forschungseinrichtungen in Berlin, Leipzig, Erlangen, Marburg, Odense und Rennes. Mit seiner Spezialisierung in Nahost- und Nordafrikastudien konzentriert sich seine Forschung vor allem auf Regionalisierungsprozesse, einschließlich transregionaler (z. B. transsaharischer) Verflechtungen, und auf aktuelle Stadtentwicklungsprozesse, insbesondere in Marokko und im Oman. 